\title{
Conceptualizing Europeanness and European Politics: Issues of Turkey's Compatibility
}

\author{
Markos Troulis \\ Faculty of Turkish Studies and Modern Asian Studies, National and Kapodistrian University, Athens, Greece
}

Email address:

mark.troulis@gmail.com

\section{To cite this article:}

Markos Troulis. Conceptualizing Europeanness and European Politics: Issues of Turkey's Compatibility. Journal of Political Science and International Relations. Vol. 1, No. 2, 2018, pp. 49-54. doi: 10.11648/j.jpsir.20180102.14

Received: July 30, 2018; Accepted: August 24, 2018; Published: September 17, 2018

\begin{abstract}
The current paper aims to describe aspects of the debate regarding Turkey's compatibility with how Europeanness is conceptualized. It is hereby questioned: How is Europe conceptualized? What's the role of history towards such conceptualizations? Which are the parameters of Europeanness? And finally, is Turkey part of Europe? These questions are found at the core of the overall problematique concerning Turkey's bid for access into the European Union (EU) and westernization process, in general. No matter how general they are, the questions refer to a certain philosophical debate which is extended to political and strategic aspects of the future of Europe as well as the future of Turkey in it. Ankara's bid for EU membership and the ongoing negotiations are identified with this extension from philosophy to politics and strategy. On this line of thought, the current paper examines the concept of Europeanness in correlation with Turkish identity and ends to examine practical issues with regard to the EU-Turkey continuing dialogue. With reference to significant bibliography, the whole series of stakes is presented as well as the overall rhetoric legitimizing Turkey's historical westernization inclinations. Therefore, the concluding remarks are related to all the practical aspects setting questions regarding Turkey's access to the EU, keeping in mind that the EU nature is absolutely different to the strategic priorities of Ankara and its policy-making practices. For this reason, with one phrase, the conclusion could be 'compatibility under conditions' beyond any historical and philosophical references, since the anti-hegemonic nature of the EU structure is clearly incompatible to a grand strategy of economic projects manipulation for political purposes and treaties revision under an aggressive argumentation of Ottoman-like domination. As far as the EU value system is still valid and it is diffused into politics and the framework within European Great Powers are organized, hegemony matters and it is avoidable.
\end{abstract}

Keywords: Turkey, European Union, Foreign Policy, Hegemonism, Europeanness

\section{Introduction}

The philosophical and theoretical background of the research refers to what Europe is. Until quite recently, a certain conceptualization of Europeanness - i.e. the European identity, the idea of Europe - was very ambitious depicting the desire for power and a global role in line with the colonial past of some of its Great Powers. By definition, this idea went beyond the historical borders of the Urals, Atlantic Ocean and the Mediterranean Sea. The idea of a Europe, which would have a spiritual mission and an ethical standing in the world and would not be just another major economic power, gave boost to a broader understanding of Europeanness as something much more than the name for a regional site of political and economic cooperation. In the modern era, the EU is dedicated to support this historical mission. In this sense, Europe needs strategic assets, such as the Turkish one. Turkey is a peer global partner and clearly a main enlargement country [1]. However, Ankara's hegemonic practices in a series of cases recently stand in contrast to the EU, which is an anti-hegemonic organization in the sense that inter-governmentalism characterizes its substance and balance of power coordinates the aims and interests of the participating actors. Under this lens, the current paper focuses on aspects of Turkey's compatibility with Europe and consequently the EU in terms of territory and borders (geography), common past (history), cultural affinities (culture), Europeanization aspects (internal politics, civil and human rights), growth (economy) as well as international relations (foreign policy mainly towards the neighboring EU member-states of Greece and Cyprus). 
On the one hand, bringing back in mind Samuel Huntington [2], it is deduced that there is a clear "ideological asymmetry" between Turkey and most of the European countries and thus, it could never enter the European Union. Since a "clash of civilizations" is unavoidable, the coexistence of countries with different values, beliefs and cultural concepts should not be endangered. On the other hand, there is an argumentation by some scholars, such as Feroz Ahmad [3], according to which Turkey is still relevant to the European continent and through it must pursue its future political orientation despite possible geographical, historical, cultural or political divergences. This argumentation is mostly strategy-oriented; i.e. in front of future dilemmas and the challenges of globalization or Europe's energy security, Turkey could constitute the linchpin between Europe and Asia and improve the EU's relations with the Muslim world. Thus, the above-mentioned debate derives from an anxiety about how materialist purposes and ambitions could fit to a philosophical and conceptual debate among scholars. In this respect, the conceptualizations of Europe and Europeanness are firstly discussed for the sake of a general framework of reference. Afterwards, Turkey's historical and strategic compatibility is described and the recent evolutions in the aftermath of the July 2016 attempt of military takeover are not neglected [4]. Before getting back to practical issues with regard to Turkey's compatibility to the "European dream", there is a short analysis on the substance of the EU integration. The latest parts of the paper are distanced from any philosophical aspects and deal more with institutional issues as well as the policy-making views of the debate.

\section{Conceptualizing Europe and Europeanness}

The historical generalized remark that "Europe is the Bible and the Greeks" gives the philosophical and theoretical background referring to what Europe is and how Europeanness is conceived. Herodotus was the first to understand Europe beyond specific territories or natural frontiers underlining that the Europeans - the "Hellenes" in his words - are distinguished from the others - the "Barbarians" - as long as they come under the power of law and "not to the will of an individual" [5]. Similarly, a couple of millennia later, Voltaire defined Europe as a "kind of great republic divided into several states" and unified under "the same principle of public law and politics" [6]. The endeavor of a common identity definition has been confronted by "the uneasy realization that not only were the origins of Europe non-European [in many aspects], but that no one could establish with any precision where Europe stopped and Asia and Africa began" [7]. Therefore, Europe is conceptualized far beyond territorial delineations rendering nowadays into an inter-state society of common historical values and political traditions. The international fragmentation co-exists with a couple of convergences on the level of periphery.
In the modern era, Europeanization processed under the principles of freedom, respect of human rights, market economy, liberal democracy as well as promotion of economic, social and territorial cohesion [8]. It was not defined in terms of borders and certainly not in line with religious or cultural affiliations, while this became practically obvious through its 2004 (Cyprus, Malta, Slovenia, Slovakia, the Czech Republic, Poland, Hungary, Estonia, Latvia and Lithuania), 2007 (Bulgaria and Romania) and 2013 (Croatia) EU enlargements. Conceptually, Europeanization has come into some kind of antithesis to Europeanness, since the first regards the adoption of acquis communautaire, the EU legal framework and the relevant norms and the second is defined in terms of self-determination and a broader cultural and historical sense. The idea of a Europe, which would have a spiritual mission and an ethical standing in the world and would not be just another major economic power, gave boost to a broader understanding of Europeanness as something much more than the name for a regional site of political and economic co-operation. It represented the ideal behind which modern Europe has been built as well as the main soft power element defining Europe's standing and influence in the global arena. This broader understanding would come as some kind of treatment to what Samuel Huntington has indicated about the formation of the international order historically:

While one-world expectations appear at the end of major conflicts, the tendency to think in terms of two worlds recurs throughout human history. People are always tempted to divide people into us and them, the in-group and the other, our civilization and those barbarians. Scholars have analyzed the world in terms of the Orient and the Occident, North and South, centre and periphery. Muslims have traditionally divided the world into Dar al-Islam and Dar al-Harb, the above of peace and the above of war [9].

Even if this sounds "too Eurocentric", it is true that the European Great Powers have determined the fate of the global arena in centuries mainly due to the time-to-time balance of power. Eurocentrism is a matter of attitude and not of content constituting the practice of viewing the world from a European perspective. It "refers to the traditional tendency of European authors to regard their civilization as superior and self-contained and to neglect the need for taking nonEuropean viewpoints into consideration" [10]. A first product of Eurocentrism has been Eurocentric historiography. In addition, the term "Eurocentric diffusionism" describes the belief according to which Europeans are considered advanced and modernized in comparison with the rest of the world which is considered traditional or less developed.

In this regard, Europe is considered the centre of the world either historically or geographically. "Eurocentric diffusionism" is a theory about the way cultural processes tend to move over the surface of the world as a whole. They tend to flow out of the European sector toward the nonEuropean sector [11]. The Eurocentric historiography defined the "conceptual borders" between what is perceived as barbarism and what is known as modernity. The problem is 
that before writing about heterogeneity, Eurocentric historians had already defined and propagated what is heterogeneous or what is considered different. This Eurocentrism has given boost to the current debate about the future of Europe and whether it is more than a continent as well as the debate on Turkey's compatibility to the EU and the European value system. The latter is considered a crucial narrative as far as it describes the essence of the post-war European integration reflecting the bipolarity and the existing balance of power.

\section{Turkey's Historical and Strategic Compatibility}

In line with Samuel P. Huntington's remarks that a "clash of civilizations" is unavoidable, there is a clear ideological and civilizational asymmetry in the way most of the European countries integrate and the European Union enlarges. Nevertheless, the broader understanding of Europeanness would come to manage this seemingly endogenous fragmentation. In these terms, a territorial, historical or cultural definition of a Europe from the Urals to the Atlantic Ocean and from the Mediterranean to the Arctic is some kind of general orientation and not a determinant and certainly, it could not exclude Turkey. Besides, historically, Turkey has been accepted as a part of the European balance power or, in other words, as an actor influencing the stability at the European periphery. It is indicative that one of the conclusions of the Paris Peace Conference in 1856 referred to the Ottoman Empire's future as "essential for European stability" [12]. Additionally, it is often argued that Turkey is relevant to the West and the EU and through them must pursue its future political orientation despite possible geographical, historical, cultural or political divergences. This argumentation is mostly strategy-oriented. Under the pressure of future dilemmas and the challenges of globalization, the current refugee crisis or Europe's energy security, Turkey could represent the linchpin between Europe and Asia and contribute to the improvement of the relations between the West and the Muslim world or the post-soviet area of the Caucasus and even Central Asia.

In this last case, it is indicative that two Turkish approaches considering the country's role in the post-Soviet area have been formulated [13]. Some analysts considered Turkey's strategic choice to approach the post-Soviet states as an alternative to its western orientation [14]. They saw this new-born world as a "shelter" for Turkey in case of western pressure against it. In that case, apart from the change of orientation, the significance of its role would increase due to its entrance in the Caucasian sub-system. Nevertheless, some others analyzed the post-Cold War redistribution of power as an opportunity for an additional - and not disjunctive strategic choice for Turkey. In this regard, Turkey could be a bridge between east and west and it is exactly this role that could increase its strategic leverage in the eyes of its western allies and especially the US. Analysts, such as Paul Henze, refer to Turkey's opportunities in the greater post-soviet area as "not contradictory or competitive", but "complementary" [15]. Furthermore, Stephen Calleya has analysed EU-Turkish relationship as a "win-win situation" through which Turkey should "seek to clearly demonstrate to the EU that it is not only capable of meeting the challenge of EU member-ship but also has a very important contribution to make to Europe's future peace and prosperity" [16]. In this regard, Europe could benefit from Turkey's multilateral policies and economic venture in the Greater Middle East, the post-soviet area and beyond.

Practically, this relationship is mutual with high potential cost and benefit for each part. For this reason, the strengthening of the EU-Turkish partnership seems to be a prerequisite for Turkey's regional power status, for instance, in the Balkans. It has been supported that "the EU and Turkey compete for influence in the region, and much hangs on Turkey's prospects for joining the 27-member European organization" [17]. This means that investment initiatives in the region have rendered Turkey into an economic power and countries, such as Bosnia, have accepted such evolutions in the name of their own Europeanization keeping in mind the so-called "Turkish model" [18]. Besides, Bosnia and Albania have been considered "frontier states" for Turkey's grand strategy by leading figures of Turkey's international relations analysis. The "Turkish model" has referred to the synthesis of Islamic morality and western-like liberalization of economy and polity mainly in the aftermath of the end of the Cold War. In this regard, Bosnia represented an example of a country inspired by this "model" in its own efforts towards accessing the EU. Thus, Turkey's historical role in the greater region is related with policy-making and the fate of some of the Southeastern European countries, while this becomes more important if it is considered that the country is located at the geopolitical backyard of the EU.

Nevertheless, are the remarks regarding EU-Turkish geographical and historical coexistence or the "win-win situation" derived from their collaboration adequate to support their compatibility? Beyond any debate concerning philosophical or territorial aspects, there is one more pragmatic and "real world" debate with regard to Turkey's political-strategic compatibility with the European Union. Essentially, it is about two different natures taking into consideration EU nature on the one hand and Turkey's grand strategy on the other. They are two different strategic cultures reflecting the way each one of them analyzes the world scene and its position vis-à-vis the main global stakes.

\section{The Substance of the EU Integration}

The structural determinants of the EU nature and the postwar integration can be defined as the absolute opposite of hegemonism and absolutism profoundly because of the deep knowledge of the causes having led to fascism's rise in the 1930s and the World War II. The Europeanization process processed on an anti-hegemonic basis and this was depicted via the stabilization of the European balance of power and 
interests as well as the abolition of past practices. In 1950, Robert Schuman stressed characteristically that "world peace cannot be safeguarded without the making of creative efforts proportionate to the dangers which threaten it" and consequently, "Europe will be built through concrete achievements which first create a de facto solidarity" [19]. Balance of power is conceptualized by one main indication; the definition of uneven growth as the basic cause of war. In this regard, the stabilization of a system is derived from how power is distributed. In the anarchic international system, where uncertainty about others' intentions is the rule, all the actors struggle to accumulate as much power as they can in order to manage their fear and survive. Consequently, the cause of fear is found in the threats to national interests and particularly to that of survival, since uneven growth causes changes with regard to elements of power, namely the means of achieving survival or even power maximization.

The balance of interests and power and the crucial abolition of hegemonism as a conception have been exemplified historically within EU institutions throughout functions such as the right to veto and the intergovernmentalism principle. On the one hand, the right to veto can be regarded as a parameter indicative of the harmonic inter-state organization. It has permitted relatively small member-states to counter decision-making, which they considered to be against their vital interests. On the other hand, intergovernmentalism is a function for the protection of the right of democratically elected governments to express their views within an inter-state partnership without being supplanted by supra-national institutions. In terms of EU treaties' provisions, the independence and self-determination of each member-state is secured and subsequently, no major actor can impose its will on others. If this changed profoundly due to hegemonic inclinations of one or more partners, then balance of power and of course, the EU itself would be weakened. The logic of anti-hegemonic counteralliances for the sake of stability and peace conceptually continues from the time of Napoleon to the modern era and the level of economic interdependence. In other words, the EU integration process is secured by the member-states themselves in the sense that groupings counter selfish policymaking practices.

Although specific conclusions about a common strategic culture cannot be reached, the EU nature described above refers to one important common characteristic of foreign policy Europeanization and some-kind "achievement of Europeanness"; i.e. anti-hegemonism. The concept of "Europeanness" usually refers to identity or historical issues. However, it is also used as a prerequisite for a country to enter and integrate into the EU. The achievement of such a prerequisite means that the objective of Europeanization will have been disseminated through foreign policy. In these terms, "Europeanness" and "Europeanization" tend to converge considering the end-product of the EU integration process [20]. Reversely, hegemonism could bring into an end a core pillar of the EU structure; i.e. balance of power. It is an important cause of war and reflects states' inclination to control as much resources as possible outside their borders implementing, in this way, imperialist policies. Such an expansion of power and interests takes place at the expense of other actors and thus, such a practice can lead to the demise of the balance of power in Europe as well as the undermining of the institutionalization derived from it. Hegemonism is absolutely inter-linked to uneven growth as far as the second is the consequence of the first and the first is resulted from the uncertainty regarding the distribution of gains in the international power gamble.

\section{Practical issues Concerning Turkey's Compatibility}

Turkish foreign policy vision and practice are inclined not to be compatible with this anti-hegemonic Europeanization legacy. Almost during the last decade, Ankara has evolved a maximalist strategic behavior - often called "neoottomanism" - which is found on the other side of the EU legacy. A closer look to Turkey's "neo-ottoman" turn leads to the identification of it with the rise of the new governing AKP elite. Even if neo-ottomanism was given boost after Turgut Özal's period (1982-1993), Erdoğan and Davutoğlu's rule has led to a more systematic approach to the objectives the neo-ottoman doctrine implies. Since 2005, when the accession negotiations started, the Europeanization has slowed down and the accession prospect is not prioritized anymore [21]. The AKP government has secured Turkey's economic growth and has "Middle Easternized" [22] its foreign policy making the country to be in less need of accessing the EU. Besides, the EU itself faces significant functional problems almost during the last decade, which have harmed its credibility. After the failed coup attempt in July 2016 and the EU member-states' anxiety considering death penalty reintroduction, Recep Tayyip Erdoğan declared indicatively that "Europe does not have the right to criticize this decision" [23]. In this regard, EU access does not seem to be a panacea for Turkey any more or, at least, it is not defined so.

Ankara has seek for quid pro quos often against basic principles of humanitarian importance of the Europeanization process, as it has done in the case of the refugee crisis. Such humanitarian provisions support EU soft power and the Union's standing in the world. Turkey has refused to ratify core provisions of the acquis communautaire, as it has happened in the case of its energy market. It refuses to withdraw its casus belli against an EU member-state even on an issue of international law included in the EU primary law; i.e. the delineation of the territorial waters in the Aegean Sea. Furthermore, it is accused of not recognizing minority rights to people of Kurdish origin. This contradiction is best reflected by two statements made by Ahmet Davutoğlu, the former foreign minister and prime minister and current Turkish parliamentarian. On the one hand, he has written that "I want to make it clear: Membership in the EU is Turkey's strategic choice and this objective is one of the most 
important projects of the Republican era" [24]. On the other hand, he has stated that the EU is not the exclusive option for Turkey and he is inclined to believe that approaching Asia is much more beneficial than joining the EU [25]. The second statement seems to be in line with Erdoğan's declarations against one-sided policies towards the West.

Additionally, the EU-Turkish fermentations with regard to the implementation of the Nabucco gas pipeline project have been an indicative example. Nabucco would be a pipeline transferring Azeri natural gas from the Caspian fields to Central European countries. Ankara neglected the acquis communautaire pressing the European Commission to unfreeze the "energy" chapter 15 of the accession negotiations. In specific, Recep Tayyip Erdoğan stated that his government would "review our position" on the Nabucco pipeline if its bid to join the EU were impaired [26]. Moreover, Turkey asked for keeping $15 \%$ of the gas having the right to re-sell it on prices defined by itself [27]. Besides, according to the Minister of Energy Hilmi Güler, Turkey is "entering into the European Union with pipelines" [28]. In other words, Turkey wanted to behave like a producer while being just a transit country. Obviously, such claims are not compatible to the EU market rules and thus, a problem arose then over Turkey's compliance with EU conditionality. They may be compatible to the logic of a state-centric strategic upgrade, but they cannot be compatible to a common logic regarding the coordination of market rules - i.e. market economy.

Another indicative example concerns the EU's stance against Turkey's initiatives in Northern Iraq. The EU has persistently stood against Turkey's practices in Northern Iraq and the continuous invasions of Turkish troops in Iraqi soil. As far as the EU's nature is anti-hegemonic and fully compatible to international law and the Westphalian legacy, state sovereignty is found at the core of its principles and policy-making. What Westphalia has offered with regard to the international system has been the respect to state sovereignty and independence. Besides, the upmost principles of international law, as they are presented in the United Nations Charter, embody the guarantees of state sovereignty, recognition of the right to self-determination and non-intervention in states' internal affairs. The EU's most important legacy has dealt mainly with the Westphalian sovereignty, since this concerns "political organization based on the exclusion of external actors from authority structures within a given territory" [29].

In these terms, the Westphalian sovereignty represents the principle securing member-states' autonomy as well as their right to self-determination even in the light of an international regime. Referring to Turkey's hegemonic practices in its region, in the aftermath of Turkish military campaigns against Kurds in Northern Iraq in 2003, a clear statement was published by the European Council according to which the leaders of the EU member-states called "on all countries of the region to refrain from actions that could lead to further instability" [30]. More specifically, EU
Commissioner Günter Verheugen declared that "any crossing of Turkish troops into northern Iraq is undesirable and will have to be taken into account in the final assessment of whether Turkey is ready to accede [to the EU]" [31].

Beyond any inspirational rhetoric considering a European value system, there is the need for a discrete standing in the global arena. The anti-hegemonic nature, the respect to human and civil rights, the market economy and the parliamentary democracy represent the pillars of the EU soft power at a time when its member-states seem incapable to compete other global actors - such as the US, Russia or China - in terms of hard power. Turkey's domestic order has been structured despotically due to the need for empowerment of the internal cohesion. Alevites, Kurds and other heterogeneous ethnic or religious groups have represented a major challenge for Turkish bureaucracy. This fragmentation has formed Turkey's foreign policy-making and has defined its core priorities and needs even at the expense of a European future.

\section{Conclusion}

Conceptually, Turkey cannot be excluded from what is defined as "Europe" or "Europeanness". However, there are several domestic and foreign policy obstacles which Turkey has to overcome in order to achieve its accession goal and the Europeanization process to come into political and strategic domains. In other words, it is not a question of historical or territorial compatibility, but one of common way of policythinking and policy-making. There are several debates with regard to Turkey's functional response to European conditionality, its inclusion in the overall project of modernization or its westernization in the sense of "identityconfiguration" [32], but the most crucial part is the adoption of the essence of the "European dream" as it is often called [33].

History, geography, culture are usually quoted for a philosophical conceptualization of Europeanness. However, the EU is a living organization with political aims and objectives based on certain values. It has formed its substance under the umbrella of common values and needs followed by the sense of solidarity and the abolition of state selfishness while this is the essence of its survival. Of course, disputes have been always present, but a common framework of understanding has been always a prerequisite for achieving Europeanization at least in the way this has been defined normatively by the EU. The ongoing evolutions regarding Recep Tayyip Erdoğan's policy-making and European leading figures' declarations leave no questions unanswered with regard to what cultivates compatibility; the EU remains an inter-state organization looking for convergence of interests in order to ally and cooperate. The current evolutions verify that Turkey remains a peer hegemon in its region and the EU aims and political narrative cannot be served under this cloak. 


\section{References}

[1] Aydin-Düzgit, S. and Tocci, N., 2015. Turkey and the European Union. London: Palgrave.

[2] Huntington, S. P., 1996. The clash of civilizations and the remaking of world order. New York: Simon and Schuster.

[3] Ahmad, F., 2003. Turkey: The quest for identity. England: Oneworld publications. $-175 \mathrm{p}$.

[4] Müftüler-Baç, M., 2018. Remolding the Turkey-EU relationship. Turkish policy quarterly, 17 (1): 119-128. - 120 p.

[5] Robbins, J. ed., 2002. Is it righteous to be?: Interviews with Emmanuel Levinas. Stanford: Stanford university press. -182 p.

[6] Pagden, A., 2002. Europe: Conceptualizing a continent. In: Pagden, A., ed. The idea of Europe: From antiquity to the European Union. New York: Cambridge university press. -37 p.

[7] Pagden, A., 2002. Europe: Conceptualizing a continent. In: Pagden, A., ed. The idea of Europe: From antiquity to the European Union. New York: Cambridge university press. -36 p.

[8] Europa, 2016. The founding principles of the Union. Available at: http://europa.eu/scadplus/constitution/objectives_en.htm [accessed 22 August 2018].

[9] Huntington, S. P., 1996. The clash of civilizations and the remaking of world order. New York: Simon and Schuster. - 32 p.

[10] Davies, N., 1997. Europe: A history. London: Pimlico. - 16 p.

[11] Blaut, J. M., 1993. The colonizer's model of the world: Geographical diffusionism and Eurocentric history. New York: The Guilford press. -1 p.

[12] Larrabee, F. S. and Lesser, I. O., 2003. Turkish foreign policy in an age of uncertainty. Santa Monica, CA: RAND Corporation. $-45 \mathrm{p}$.

[13] Keyman, E. F., 2017. A new Turkish foreign policy: Towards proactive "moral realism". Insight Turkey, 19 (1): 55-70.

[14] Akyuz, H. and Hess, S., 2018. Turkey looks East: International leverage and democratic backsliding in a hybrid regime. Mediterranean quarterly, 19 (2): 1-26.

[15] Hale, W., 2003. Turkish foreign policy: 1774-2000. London: Frank Cass. -194 p.

[16] Calleya, S. C., 2006. EU-Turkish relations: Prospects and problems. Mediterranean quarterly, 17 (12): 40-47. - 46-47 p.

[17] Brljavac, B., 2011. Turkey entering the European Union through the Balkan doors: In the style of a Great Power? The Turkish yearbook of international relations, $42: 61-75 .-73 \mathrm{p}$.

[18] Troulis, M., 2016. Challenges of metamorphosis in the Middle
East: Religion-politics relations under construction. In: Mercan, M. H., ed. Transformation of the Muslim World in the 21st century. London: Cambridge publishing scholars, $117-130$.

[19] Europa, 2016. The Schuman declaration - 9 May 1950. Available at: http://europa.eu/about-eu/basicinformation/symbols/europe-day/schumandeclaration/index_en.htm [accessed 22 August 2018].

[20] Best, H., 2012. Elite foundations of European integration: A causal analysis. In: Best, H., Lengyel, G. and Verzichelli, L., eds. The Europe of elites: A study into the Europeanness of Europe's political and economic elites. Oxford: Oxford university press. $-210 \mathrm{p}$.

[21] Alessandri, E., 2011. Turkey's future reforms and the European Union. Turkish policy quarterly, 10 (1): 69-78. - 71 p.

[22] Perthes, V., 2018. Conflict and realignment in the Middle East. Survival, 60 (3): 95-104.

[23] Jones, G. and Kandemir, A., 2016. Erdogan declares state of emergency, tells EU to shut up. Arab news. Available at: http://www.arabnews.com/node/956976/middle-east [accessed 20 August 2018].

[24] Davutoğlu, A., 2009. Turkish foreign policy and the EU in 2010. Turkish policy quarterly, 8 (3): 11-17.

[25] Davutoğlu, A., 2010. The strategic depth: Turkey's international position (in Greek). Athens: Piotita. $-756 \mathrm{p}$.

[26] Deutsche Welle, 2016. Turkey blackmailing EU over gas pipeline, German minister says. Available at: http://www.dwworld.de/dw/article/0,,3962409,00.html [accessed 20 August 2018].

[27] NTV, 2017. Rus doğalgazına alternatif arayışı. Available at: http://arsiv.ntv.com.tr/news/458088.asp [accessed 21 August 2018].

[28] Bacik, G., 2006. Turkey and pipeline politics. Turkish studies, 7 (2): 293-306. - 304 p.

[29] Krasner, S. D., 1999. Sovereignty: Organized hypocrisy. New Jersey: Princeton university press. $-3-4 \mathrm{p}$.

[30] Fokas, E., 2004. The Islamist movement and Turkey-EU relations. In: Uğur, M. and Canefe, N., eds. Turkey and European integration: Accession prospects and issues. London: Routledge. - $162 \mathrm{p}$.

[31] Fokas, E., 2004. The Islamist movement and Turkey-EU relations. In: Uğur, M. and Canefe, N., eds. Turkey and European integration: Accession prospects and issues. London: Routledge. $-162 \mathrm{p}$.

[32] Cardwell, P. J., 2018. Explaining the EU's legal obligation for democracy promotion: The case of the EU-Turkey relationship. European papers, 2 (3): 863-886.

[33] Rifkin, J., 2004. The European dream: How Europe's vision of the future is quietly eclipsing the American dream. New York: Perigee. 